\title{
Pengembangan Personalisasi Gaya Belajar pada E-learning dengan Menggunakan Felder Silverman Learning Style Model untuk Sekolah Menengah Kejuruan (SMK)
}

\author{
Ayi Muhammad Iqbal Nasuha \\ Pendidikan Ilmu Komputer, FPMIPA \\ Universitas Pendidikan Indonesia \\ Bandung, Indonesia \\ muh.iqbal.n@gmail.com
}

\author{
Mira Suryani \\ Fakultas Ilmu Komputer \\ Universitas Indonesia \\ Depok, Indonesia \\ mira.suryani@ui.ac.id
}

\begin{abstract}
The development of e-learning growth up continuosly. Now, e-learning becomes more adaptif with personalization which can detect the characteristic and individual needs of student. In order to create personalized learning in vocational high school, the system with visual/verbal dimentional by Felder Silvermen was developed. The system has the prosposed algorithm which can decided what type of learning materials (visual/verbal) that can be delivered to students according to their learning sytle. After the implementation stage, the system were used by the students in Insan Mandiri Vocasional School. Questionnares were spread to all participants including lecturer and teacher to obtain the feasilibility and satisfability of the proposed system. The results shows that $82,14 \%$ the system feasible to use by students with well functionality and the experts said that $75,79 \%$ the system can be used as well learning media.
\end{abstract}

Keywords—personalized learning, felder silverman, learning style, visual-verbal

Abstrak-Saat ini perkembangan e-learning terus berkelanjutan. E-learning menjadi semakin adaptif dengan adanya personalisasi e-learning yang dapat mendeteksi karakteristik dan kebutuhan individu dari siswa. Dengan tujuan menciptakan sebuah personalisasi e-learning untuk lingkungan sekolah menengah kejuruan, dikembangkanlah personalisasi elearning yang mengadopsi dimensi visual/verbal dari Felder Silverman. Sistem memiliki sebuah algoritma yang dapat menentukan tipe materi pembelajaran (visual/verbal) yang dapat yang sesuai dengan gaya belajar siswa. Setelah tahapan pengembangan sistem, sistem diujicobakan ke siswa di SMK Insan Mandiri. Kuisioner disebar ke seluruh partisipan termasuk guru dan dosen sebagai ahli untuk mengetahui tingkat kelayakan dan kepuasan dari sistem yang diusulkan. Hasil yang diperoleh menunjukkan $82,14 \%$ siswa menyatakan bahwa sistem layak digunakan dalam pembelajaran dan memiliki fungsionalitas yang baik. Selain itu, para ahli menilai sistem memiliki kelayakan $\mathbf{7 5 , 7 9 \%}$ untuk digunakan sebagai media yang mendukung pembelajaran di sekolah.
Kata kunci-personalisasi e-learning, felder silverman, gaya belajar, visual-verbal,

\section{Pendahuluan}

Tidak dapat dipungkiri, internet memberikan kemudahan dalam mengakses berbagai jenis data termasuk data pendidikan. Adanya internet memacu berbagai inovasi dalam dunia pendidikan, salah satunya dengan dikembangkannya elearning untuk berbagai jenjang pendidikan. E-learning merupakan sebuah konsep dalam proses pembelajaran yang menggunakan media Teknologi Informasi dan Komunikasi (TIK), khusunya berbasis internet atau website [1]. E-learning berfungsi sebagai media pendukung pembelajaran tatap muka. Dalam mengimplementasikan e-learning, diperlukan kesiapan baik dari sisi guru sebagai fasilitator dan siswa sebagai penerima materi yang memiliki motivasi belajar mandiri.

E-learning dikembangkan secara terus menerus sehingga mampu membantu guru menyampaikan tidak hanya nilai kognitif, tetapi juga nilai afektif dan psikomotorik. Hingga saat ini e-learning berkembang ke arah yang lebih adaptif, dimana e-learning yang ada, mampu mengenal karakteristik dan kebutuhan pribadi siswa. Istilah pembelajaran adaptif dengan e-learning ini disebut dengan personalisasi e-learning. Pengenalan karakteristik siswa ini diharapkan dapat mempermudah guru dalam memberikan materi pembelajaran yang sesuai dengan yang dibutuhkan oleh siswa. Selain itu, siswa juga diharapkan untuk dapat mengeluarkan usaha terbaiknya dalam proses pembelajaran [2].

Dalam proses implementasi, personalisasi e-learning ternyata bukan sesuatu yang mudah untuk dilakukan hal ini dikarenakan begitu kompleksnya karakteristik siswa. Namun, seperti yang disampaikan Sfenrianto, Untuk mendapatkan sistem e-learning yang optimal, bukan hanya penyediaan materi yang harus diperhatikan tetapi juga faktor gaya belajar peserta didik [3]. Oleh karena itu, dalam paper ini diusulkan sebuah inovasi mengenai pengembangan personalisasi e- 


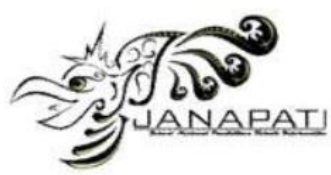

learning. Pendekatan yang digunakan dalam mengembangkan personalisasi e-learning yaitu melalui pendekatan Felder Silverman Learning Style Model (FSLSM). Pada penelitian ini, dimensi gaya belajar yang menjadi fokus yaitu visual atau verbal. Adapun tujuan dari pengembangan sistem personalisasi ini adalah memberikan inovasi dalam hal kenyamanan dan lebih jauh lagi mengenai peningkatan efektivitas dalam proses pembelajaran.

\section{Studi literatur}

\section{A. Konsep E-learning}

Menurut Almrashdah et al, e-learning atau yang lebih dikenal dengan online learning merupakan terminologi yang muncul ketika teknologi secara general digunakan untuk merepresentasikan kegiatan pendidikan pada sebuah komputer [4]. E-learning merupakan lonjakan inovasi dalam dunia pendidikan yang memberikan banyak manfaat dan kemudahan untuk menjalankan proses belajar mengajar. Tujuan dari adanya e-learning seperti yang dikemukakan Reyes et al adalah menyediakan informasi bagi siswa dan memungkinkan siswa untuk melakukan kegiatan praktikum untuk mendapatkan tambahan kemampuan tertentu yang dapat dilakukan baik disekolah maupun diluar sekolah [5]. Selain itu, e-learning juga memungkinkan siswa belajar secara mandiri untuk meningkatkan pengetahuan mengenai topik pembelajaran yang disenanginya. Dengan adanya e-learning, diharapkan pembelajaran menjadi lebih berkesan.

Terdapat banyak aspek yang menjadi kelebihan e-learning apabila dibandingkan dengan pembelajaran konvensional, dimana e-learning memiliki tingkat fleksibilitas waktu dan tempat yang tinggi, komunikasi yang lebih personal, akses luas ke sumber materi pembelajaran, dan kecepatan belajar dapat diatur pribadi [6].

\section{B. Gaya Belajar (Learning Style)}

Gaya belajar atau learning style merupakan perkembangan dari cognitive style yang digunakan untuk membedakan kegiatan belajar seseorang berdasarkan cara orang tersebut memproses informasi. Lebih jauh lagi gaya belajar dapat dibedakan ke dalam dua kutub dimensi dimana satu dimensi memiliki dua ekstrim [7]. Menurut Somyurek, untuk mengetahui karakteristik siswa, dapat dilakukan melalui tiga cara [8], yaitu:

1) Pertanyaan langsung (direct questions), metode ini dengan menggunakan kuisioner atau angket sebagai instrumen untuk mendapatkan informasi dari peserta didik langsung mengenai karakter gaya belajarnya.

2) Asumsi (assumptions), menggunakan suatu bentuk model peserta didik untuk melengkapi informasi yang sudah didapatkan sebelumnya. Contoh asumsi digunakan untuk melengkapi sebagian kecil informasi yang kosong dalam pengisian kuisioner oleh siswa.
3) Interaksi peserta didik dengan sistem (learner-system interaction), informasi diperoleh dari interaksi peserta didik dengan sistem e-learning, sehingga diperoleh suatu rekam jejak gaya belajar yang dapat diolah menjadi rekomendasi gaya belajar.

\section{Felder Silverman Learning Style Model (FSLSM)}

FSLSM merupakan salah satu teori gaya belajar yang diusulkan oleh Felder dan Silverman pada tahun 1988 [9]. Berdasarkan banyak hasil penelitian, FSLSM merupakan learning style yang paling sesuai untuk diaplikasikan dalam elearning atau pembelajaran online lainnya. Secara jelas, teori FSLSM membedakan preferensi atau karakteristik siswa dalam menerima dan mengolah informasi ke dalam empat dimensi [10]. Empat dimensi tersebut antara lain: 1) dimensi aktif/reflektif, 2) dimensi sensing/intuitive, 3) dimensi visual/verbal, dan 4) sekuensial/qlobal. Dalam penelitian ini pembahasan mengenai FSLSM lebih di fokuskan pada dimensi visual/verbal.

Dimensi ketiga merupakan dimensi mengenai bentuk informasi yang diterima siswa. Dimensi ini dibagi ke dalam dua jenis yaitu visual dan verbal. Siswa dengan preferensi visual lebih senang menerima materi yang dapat dilihat seperti grafik, video, dan sejenisnya sedangkan siswa dengan preferensi visual lebih senang mendapatkan materi secara verbal seperti ceramah, rekaman audio, atau diskusi langsung.

\section{Metodologi}

Gambar 1 menunjukkan secara rinci tahapan pengembangan sistem personalisasi e-learning yang diusulkan. Personalisasi e-learning berdasarkan dimensi visual/verbal dari FSLSM merupakan personalisasi yang menitikberatkan pada pengembangan sistem yang mampu mendeteksi karakteristik seseorang baik verbal maupun visual. Selanjutnya setelah diketahui kecenderungan karakteristik dari seorang siswa, kemudian diberikan arahan atau rekomendasi bagi siswa untuk lebih memperbanyak mengakses materi pembelajaran yang sesuai dengan karakteristiknya. 

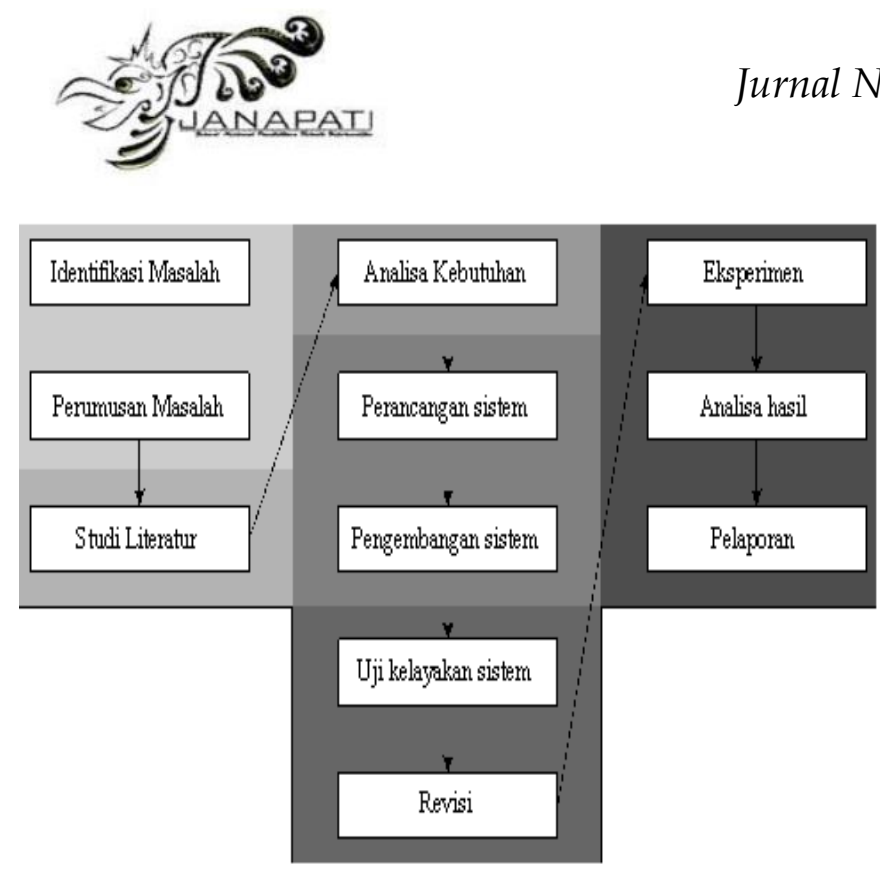

Gambar 1. Tahapan pengembangan sistem

Adapun rancangan sistem personalisasi yang dikembangkan dapat dilihat pada gambar 2 berikut.

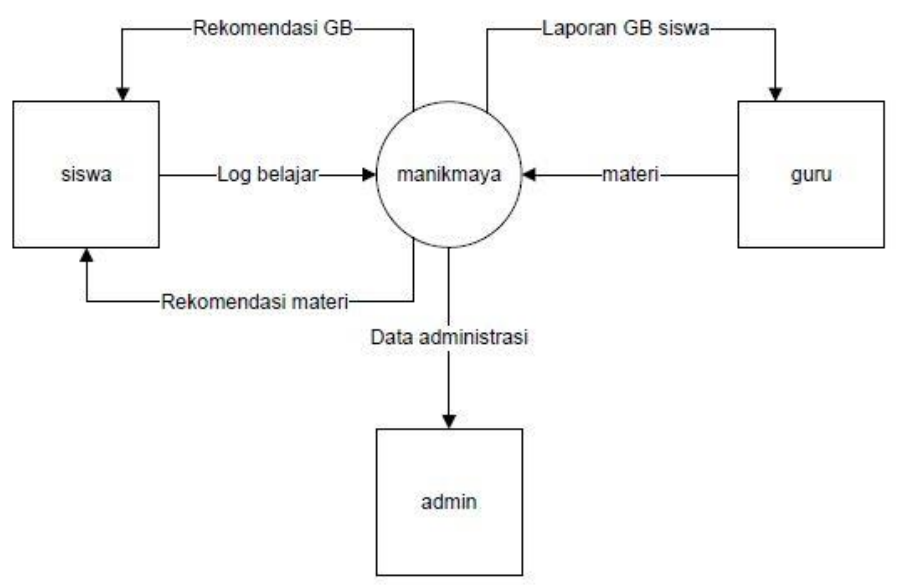

Gambar 2. Rancangan sistem personalisasi e-learning visual/verbal

Gambar 2 menunjukkan bahwa proses personalisasi dimulai dengan aktivitas siswa dalam menggunakan elearning. Pada awal pembelajaran, inisialisasi gaya belajar dari siswa diperoleh dari hasil kuisioner FSLSM. Kemudian hasil dari kuisioner tersebut digunakan sebagai dasar untuk pemberian jenis materi awal yang sesuai dengan gaya belajarnya. Pada tahapan selanjutnya, selama proses pembelajaran, aktivitas siswa dalam mengakses e-learning disimpan ke dalam log. Kemudian data log diekstrak oleh sistem yang diberi nama "Manikmaya". Sistem akan memberikan laporan gaya belajar kepada guru. Setelah itu, guru akan memberikan materi yang sesuai dengan gaya belajar siswa ke dalam sistem. Pada akhirnya sistem akan meneruskan materi dari guru ke siswa disertai dengan rekomendasi gaya

belajar apakah sebaiknya tetap di visual atau disarankan beralih ke verbal.

Pada tahapan pemberian materi dan rekomendasi gaya belajar. Pada penelitian ini juga dirancang konsep dari penentuan keputusan pemberian rekomendasi. Konsep penentuan keputusan materi dan rekomendasi gaya belajar dapat dilihat pada gambar 3 .

Tahapan penentuan keputusan pemberian materi dan rekomendasi dimulai dengan diambilnya data log akses ke materi pembelajaran. Data log diambil dari database kemudian dilakukan pengecekan bentuk materi apakah termasuk materi verbal atau visual. Kemudian jumlah akses untuk masingmasing jenis materi dihitung dan dibandingkan manakah jenis materi yang paling banyak diakses oleh siswa. Materi yang paling banyak diakses akan menjadi rekomendasi utama dalam memberikan jenis materi yang sesuai dengan karakteristik siswa. Apabila terdapat kemungkinan siswa ingin berpindah karakteristik, maka guru akan mendapatkan peringatan untuk membandingkan jejak rekam siswa dengan rekap nilai pembelajaran yang diperoleh. Kemudian guru dapat memberikan rekomendasi siswa tersebut disarankan untuk berpindah gaya belajar atau tetap dengan gaya belajar sebelumnya. 

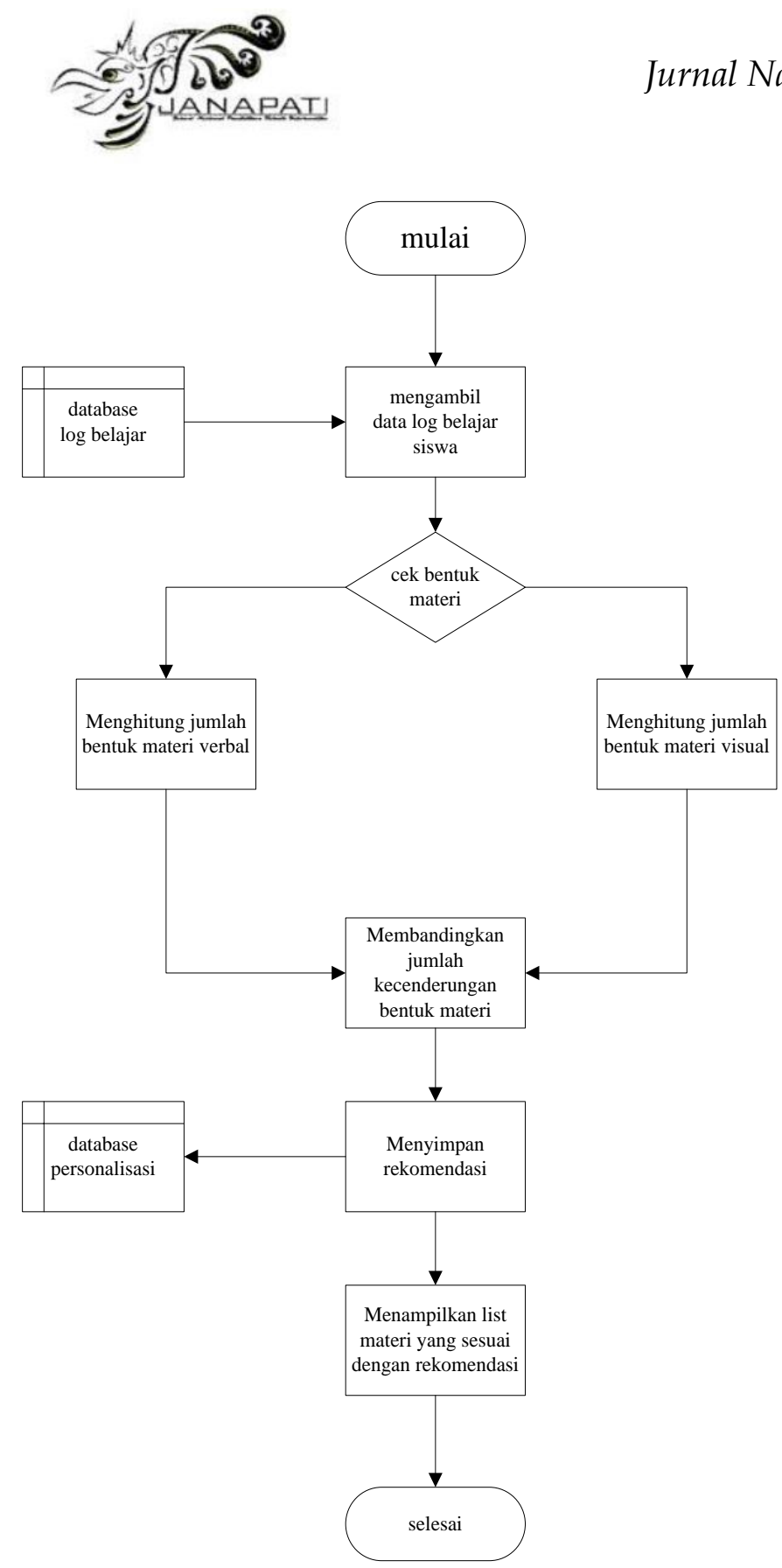

Gambar 3. Flowchart penentuan pemberian materi dan rekomendasi pada personalisasi e-learning.

\section{Iv. Persiapan Uji Coba}

\section{A. Lokasi dan Subjek Penelitian}

Lokasi yang menjadi tempat penelitian yaitu Sekolah Menengah Kejuruan Insan Mandiri, Kabupaten Bandung Barat. Subjek penelitian yang digunakan dalam penelitian ini adalah siswa dan guru mata pelajaran kelas X dan XI. Subjek ini dipilih berdasarkan pertimbangan pengetahuan TIK, aktivitas akademis, dan kebijakan pihak sekolah. Dalam penelitian ini, pengambilan sampel dilakukan dengan menggunakan metode Simple Random Sampling dimana pengambilan sampel dilakukan secara acak tanpa memperhatikan strata yang berada dalam populasi seperti prestasi, tingkat ekonomi, jurusan, dan sebagainya. Sampel yang digunakan dalam penelitian adalah satu kelas dari keseluruhan kelas $\mathrm{X}$ dan XI yang berada di SMK Insan Mandiri.

\section{B. Desain Penelitian}

Mengacu kepada [11], desain penelitian yang digunakan untuk kasus ini adalah One Shot Case Study berjenis desain evaluasi sebuah kelompok. Dalam penelitian hanya ada satu buah kelompok yang akan diberikan perlakuan kemudian dilanjutkan dengan evaluasi. Perlakukan merupakan sebuah aktivitas dimana siswa dan guru mata pelajaran diminta menggunakan sistem yang dibangun peneliti. Selanjutnya khusus untuk siswa, diberikan evaluasi berupa kuisioner untuk memberikan penilaian dan menentukan tingkat kepuasan dari sistem yang dibangun. Ilustrasi desain penelitian dilihat pada gambar 4 berikut.

\section{$\mathrm{X} \mathrm{O}$}

Keterangan:

$\mathrm{X}$ : perlakuan, $\mathrm{O}$ :evaluasi

Gambar 4. Desain penelitian One Shot Case Study

\section{Instrumen Penelitian}

Setelah uji coba sistem dilakukan, maka selanjutnya dilakukan tahapan evaluasi. Pada penelitian ini, evaluasi difokuskan pada aspek fungsionalitas dan tingkat kepuasan pengguna terhadap sistem yang dikembangkan. Terdapat dua instrumen yang digunakan dalam evaluasi. Instrumen pertama,form penilaian kuisioner yang akan digunakan untuk expert judgement. Expert judgement berguna untuk mengetahui tingkat kelayakan dari sistem yang dikembangkan. Instrumen kedua berupa kuisioner yang akan diberikan kepada siswa dan guru untuk mengetahui menilai fungsionalitas dan tingkat kepuasan dari penggunaan sistem yang dibangun.

Skala pengukuran yang digunakan dalam form penilaian dan kuisioner adalah skala Likert (Likert Scale). Untuk menghitung nilai dari form penilaian dan kuisioner, peneliti menentukan skor ideal. Skor ideal merupakan skor yang ditetapkan dengan asumsi peneliti menjawab semua pertanyaan atau pernyataan dengan nilai tertinggi. Kemudian dilakukan pembagian antara jumlah nilai yang sebenarnya dari tiap responden dengan skor ideal [11]. Adapun untuk form penilaian sistem untuk para ahli akan menggunakan skor $1-5$, dimana 1 merupakan skor minimum dan 5 merupakan skor maksimum untuk menentukan tingkat kelayakan dari sistem. 
Untuk mengolah data yang diperoleh dari penilaian para ahli dan siswa, peneliti menggunakan perhitungan rating scale. Adapun perrhitungan rating scale menggunakan rumus berikut:

$$
P=\frac{\text { skor hasil pengumpulan data }}{\text { skor ideal }} \times 100 \%
$$

Keterangan:

$\mathrm{P}=$ persentase, Skor ideal $=$ skor maksimal tiap butir $\mathrm{x}$ jumlah responden $\mathrm{x}$ jumlah butir.

\section{v. Pembahasan Hasil Uji Coba}

Setelah melalui tahapan pengembangan sistem. Sistem kemudian diujicobakan ke kelompok sampel yang telah dipilih. Adapun antarmuka sistem personalisasi e-learning yang dikembangkan dapat dilihat pada gambar 5 berikut.

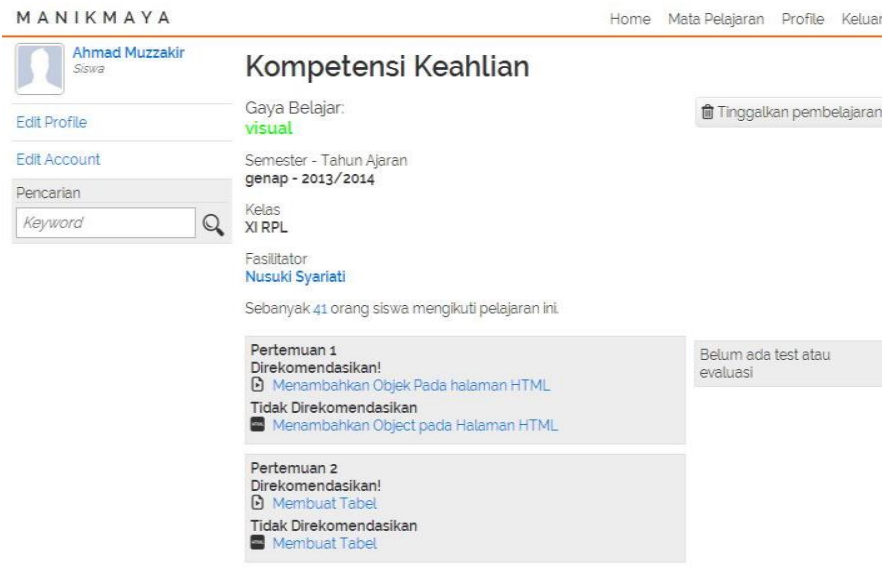

Gambar 5. Tampilan antarmuka pengguna sistem personalisasi e-learning visual/verbal

Dikarenakan tujuan dari penelitian ini adalah mengetahui, kelayakan, fungsionalitas, dan kepuasan dari sistem yang dikembangkan maka uji coba dilakukan selama 2 pertemuan pada pembelajaran kompetensi dasar di SMK. Dari hasil pengolahan kuisioner, diperoleh penilaian siswa terhadap sistem yang dikembangkan. Hasil penilaian secara rinci dapat dilihat pada tabel 1 berikut.

Tabel 1. Hasil Penilaian Siswa Terhadap Sistem E-LEaRning UsUlan

\begin{tabular}{|l|c|}
\hline \multicolumn{1}{|c|}{ Aspek Penilaian } & $\begin{array}{c}\text { Perolehan } \\
\text { Skor }\end{array}$ \\
\hline Aspek Umum (2 indikator) & 343 \\
\hline Aspek Visual (6 indikator) & 940 \\
\hline $\begin{array}{l}\text { Aspek Personalisasi Gaya Belajar (2 } \\
\text { indikator) }\end{array}$ & 332 \\
\hline Aspek Pembelajaran (1 indikator) & 147 \\
\hline Total Perolehan Skor & $\mathbf{1 7 6 2}$ \\
\hline Skor Kriterium & $\mathbf{2 1 4 5}$ \\
\hline
\end{tabular}

Skor kriterium atau skor maksimal adalah $11 \times 5 \times 39=$ 2145. Dimana nilai 40 adalah jumlah responden siswa yang mengisi angket, nilai 5 adalah nilai ideal setiap butir pertanyaan, dan 11 adalah jumlah butir pertanyaan dalam angket.

Dari penelitian yang telah dilakukan, didapat nilai 1762 sebagai total perolehan skor yang didapat oleh peneliti dari penilaian 39 responden siswa. Apabila dibandingkan dengan skor kriterium maka didapat $1762: 2145=0,8214$ atau jika di presentasikan menjadi $82,14 \%$. Dari hasil tersebut maka siswa memberikan penilaian yang dengan kategori sangat baik terhadap sistem yang dikembangkan berdasarkan Kategori Kelayakan Sistem [12].

Penilaian sistem hanya oleh siswa meskipun guru terlibat dalam uji coba sistemnya, namun dalam hal ini peneliti hanya fokus pada pengembangan personalisasi rekomendasi materi pembelajaran untuk siswa. Jadi sasaran utama dalam penelitian ini adalah siswa dalam mendapatkan rekomendasi materi.

Selanjutnya penilaian terhadap sistem yang dilakukan oleh para ahli. Dalam hal ini, penilaian sistem melibatkan 2 orang dosen yang ahli dalam bidang sistem informasi dan e-learning. Adapun hasil penilaian dari para ahli dapat dilihat pada table 2 berikut.

TABel 2. Hasil Penilaian Para Ahli

\begin{tabular}{|c|c|c|c|c|c|}
\hline No & Aspek & $\begin{array}{c}\text { Skor } \\
\text { Kriterium }\end{array}$ & $\begin{array}{c}\text { Jumlah } \\
\text { penguji }\end{array}$ & $\begin{array}{c}\text { Perolehan } \\
\text { Skor }\end{array}$ & Presentase \\
\hline 1. & Umum & 30 & 2 & 20 & $66,67 \%$ \\
\hline 2. & VF & 70 & 2 & 59 & $84,29 \%$ \\
\hline 3. & RPL & 60 & 2 & 42 & $70,00 \%$ \\
\hline 4. & PGB & 40 & 2 & 32 & $80,00 \%$ \\
\hline 5. & Pembelajaran & 50 & 2 & 39 & $78,00 \%$ \\
\hline \multicolumn{7}{|c|}{ Rata-rata Skor } \\
\hline
\end{tabular}

Keterangan:

VF : Visual dan Fungsionalitas

RPL : Rekayasa Perangkat Lunak

PGB : Personalisasi Gaya Belajar

Dari tabel di atas dapat dilihat bahwa validasi yang dilakukan para ahli untuk mengetahui kelayakan dan keberfungsionalan sistem yang dikembangkan mendapatkan nilai rata-rata presentase $75,79 \%$ yang dapat dikategorikan baik. Secara kontium bisa dilihat pada gambar 6 berikut.

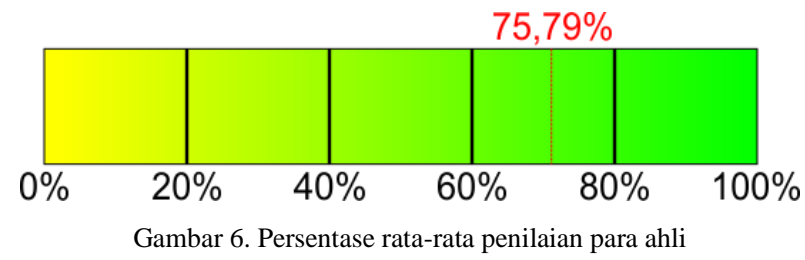




\section{vI. Kesimpulan}

Personalisasi e-learning dapat memberikan kenyamanan lebih dalam proses pembelajaran menggunakan e-learning. Personalisasi e-learning dapat dilaksanakan tidak hanya di tingkat perguruan tinggi namun di tingkat sekolah menengah. Penelitian ini membuktikan bahwa personalisasi e-learning yang menggunakan adopsi konsep visual/verbal dari FSLSM mendapatkan sambutan yang baik dari penggunanya.

Tahapan dalam penelitian diawali dengan mengeksplorasi keberagaman gaya belajar yang dimiliki 40 siswa dari kelas XI RPL dengan menyebar kuisioner. Dan didapati hasilnya adalah gaya belajar siswa kelas XI RPL di SMK Insan Mandiri memiliki gaya belajar yang beragam, dengan $90 \%$ siswa di kelas tersebut memiliki gaya belajar visual dan sisanya sebanyak $10 \%$ siswa memiliki gaya belajar verbal. Setelah data didapatkan dapat dianalisis suatu kebutuhan adanya personalisasi dalam bentuk materi pembelajaran yang sesuai dengan gaya belajar masing-masing siswa. Kemudian sistem dikembangkan dan diujicobakan.

Berdasarkan data yang telah dijelaskan sebelumnya, penilaian sistem menurut 39 siswa adalah 82,14\%. Di mana berdasarkan kategori kelayakan sistem, nilai tersebut masuk dalam kategori sangat baik. Berdasarkan data yang telah dijelaskan sebelumnya, penilaian sistem menurut 2 orang ahli adalah 75,79\%. Di mana berdasarkan kategori kelayakan sistem, nilai tersebut masuk dalam kategori sangat baik.

\section{Saran Penelitian Selanjutnya}

Dari penelitian yang telah dilakukan, terdapat beberapa rekomendasi pengembangan yang dapat dikembangkan selanjutnya, antara lain:

1) Penggunaan fasilitas chatting secara realtime menjadi salah satu fitur yang sangat dibutuhkan, tetapi tentu saja dengan adanya batasan-batasan tertentu agar fitur ini menjadi efektif dalam penggunaannya.

2) Untuk efektivitas kerja, sebaiknya sistem dilengkapi dengan fasilitas ekspor/import data.

3) Penambahan personalisasi dalam bentuk lainnya, seperti personalisasi pola pembelajaran, konsep pemahaman, dan aktifitas peserta didik.
4) Pengujian sistem tidak hanya berhenti sampai kelayakan, kepuasan, dan fungsionalitas saja tetapi juga dapat berkembang ke peningkatan hasil belajar siswa.

\section{References}

[1] Li, Y. \& S. Zhao. (2010). An Association Rule Mining Approach for Intelligent Tutoring System. Proceedings of 2nd International Conference on Computer Engineering and Technology. IEEE, Chengdu. pp. V6-460-V6-464

[2] Graf, S. \& Kinshuk. (2008). Adaptivity and Personalization in Ubiquitous Learning Systems. Proceedings of the Symposium on Usability and Human Computer Interaction for Education and Work (USAB 2008), International Workshop on Adaptivity and Personalization in Ubiquitous Learning Systems (APULS 2008). Graz

[3] Sfenrianto. (2010). Klasifikasi Gaya Belajar Verbal dan Visual dari Peserta Didik untuk Sistem e-learning Adaptif. Konferensi Nasional Informatika (KNIF 2010)

[4] Almrashdah, I. A., et al. (2010).Distance Learners Acceptance of Learning Management System. Proceeding of 6th International Conference on Advance Information Management and Service. IEEE, Seoul. pp. 304-309.

[5] Reyes, N. R., et al (2009). Comparing Open-source E-learning Platforms from Adaptivity Point of View. Proceeding of EAEEIE Annual Conference.IEEE, Valencia. pp. 1-6.

[6] Saracevic, et all. (2008). Comparative Analysis of The Success Studying Students Attending Traditional Learning or E-learning. Proceeding of International Conference on Information Technology and Development of Education. Technical Faculty "Mihajlo Pupin”, Serbia, 2008. pp. 326 $-332$

[7] Logan, Kit dan Pete Thomas. (2002). Learning Style in Distance Education Students Learning to Programs. In J. Kuljis, L. Baldwin \& R. Scoble (Eds). Proc. PPIG 14. 14th Workshop of the Psychology of Programming Interest Group, Brunel University. pp. 29-44.

[8] Somyürek, S. (2009). Student modeling: Recognizing the individual needs of users in e-learning environments. International Journal of Human Sciences vol.6 no. 2.

[9] Felder, Richard M., dan Barbara A. Soloman. (1988). Learning Style and Strategies. [Online]. Tersedia: http://www4.ncsu.edu/unity/lockers/users/f/felder/public/ILSdir/styles.ht m [17 Agustus 2013]

[10] Graf, Sabine, Silvia Rita Viola, dan Kinshuk. (2007). Automatic Student Modelling for Detecting Learning Style Preferences in Learning Management Systems. Proceeding of the IADIS International Conference on Cognition and Exploratory Learning in Digital Age (CELDA 2007), Algarve, Portugal, 2007. P. 172-179.

[11] Ruseffendi, E.T. (2005). Dasar-dasar Penelitian Pendidikan dan Bidang Non-Eksakta Lainnya. Bandung: Tarsito.

[12] Gonia, Daus. (2009). Skripsi. Program Studi Ilmu Komputer, Program Ilmu Komputer. Universitas Pendidikan Indonesia. 